SCJR 13, no. 1 (2018): 1-2

\title{
Nina Caputo and Illustrated by Liz Clarke Debating Truth: The Barcelona Disputation of 1263, A Graphic History
}

(New York, NY: Oxford University Press, 2016), 256 pp.

PAOLA TARTAKOFF

tartakoff@gmail.com

Rutgers University, New Brunswick, NJ 08901

Debating Truth: The Barcelona Disputation of 1263, A Graphic History brings to life one of the most momentous Jewish-Christian disputations of the Middle Ages, the public debate between Nahmanides (Rabbi Moses ben Nahman, c. 1195-1270) and the Jewish convert to Christianity Friar Paul (Pablo Christiani, d. 1274) that was convened in Barcelona in 1263 by King James I of Aragon (1213-1276). At this disputation, which was attended by throngs of onlookers including secular and lay leaders, Friar Paul showcased a new method for trying to convert Jews to Christianity: he sought to demonstrate the truth of Christianity on the basis of passages from rabbinic literature. Nahmanides, arguing largely from a defensive position, challenged Christiani's interpretations.

The Barcelona Disputation has fascinated generations of historians, especially because both Hebrew and Latin accounts of the disputation survive. The Hebrew account was penned by Nahmanides; the shorter anonymous Latin account was produced at the court of King James. These two narratives recount a similar sequence of themes, but not surprisingly they differ in their judgments about who won specific arguments and the debate as a whole. In his detailed description, Nahmanides celebrated his boldness and his perception of his superior knowledge and acuity. The Latin description, by contrast, claimed that Friar Paul easily vanquished his Jewish interlocutor. Together, these two narratives have enabled scholars to compare a Jewish and a Christian perspective on the disputation, gaining greater insight into their authors' aspirations. The contradictions between these two texts have presented challenges, however, for determining what actually happened.

Debating Truth does a splendid job of conveying the complexity of the Barcelona Disputation itself as well as the complexity of attempting to reconstruct this important event. Roughly following the format of other volumes in Oxford 
University Press's Graphic History Series, the volume unfolds in five parts, each of which provides a fresh point of entry for considering these subjects. Part I is a masterfully illustrated, five-chapter graphic adaptation of the disputation. The first three chapters closely follow Nahmanides' account, quoting or paraphrasing much of the dialogue. Chapter Four dramatizes the Latin account. Chapter Five focuses on the aftermath of the disputation, including Nahmanides' journey to the land of Israel. Liz Clarke's meticulous drawings enrich readers' understanding and appreciation of the developments they depict. Action-packed and expressive, they clarify the tone of many utterances and vividly portray the various settings, from the royal court and its surroundings to Jerusalem and Acre.

The remainder of the book provides readers with resources for the study of this period. Part II presents carefully annotated English translations-many of them new - of primary sources relevant to the Barcelona Disputation. These documents include the Hebrew and Latin accounts of the disputation, letters that King James I sent to the Jews of his kingdom, a letter that Nahmanides wrote to his son upon his arrival in Jerusalem, and selected canons on the Jews from the Fourth Lateran Council of 1215. This well-organized collection of texts enables readers to consult the sources on which the graphic novel is based. Part III narrates important background information that is essential to a fuller understanding of the disputation. It discusses the place of Iberia in medieval Christendom, the life of King James I, the history of the Jews who lived in Spain, and the role of disputation in medieval culture. Concise and illustrated with attractive maps, this section is easily accessible to undergraduates. Part IV surveys the historiography of the Barcelona Disputation, starting with the history of the production and transmission of the Hebrew and Latin accounts of the disputation, continuing through early modern and late-nineteenth century developments, and including a discussion of recent approaches. Most compellingly, this section also recounts the process of making Debating Truth, laying bare how history continues to be rewritten and, in this case, visually reimagined as well. Illustrations grace this section of the book, too, showing readers medieval manuscripts and illuminations, as well as draft and discarded drawings for Debating Truth. Part V completes this rich volume with lists of additional resources and questions for further research as well as a glossary.

Lucid, erudite, and imaginative, Debating Truth is a valuable resource for teaching undergraduates and graduate students about medieval history, JewishChristian relations, and historical methods. Students and instructors alike will welcome its compact and engaging format, which harnesses the visual power of graphics to maximum effect. 